\title{
Mitochondrial involvement in aspirin-induced apoptosis in yeast
}

Correspondence

Rena Balzan

rena.balzan@um.edu.mt

Received 29 January 2008

Revised 17 June 2008

Accepted 19 June 2008
Karen Sapienza, William Bannister and Rena Balzan

Department of Physiology and Biochemistry, University of Malta, Msida MSD 2080, Malta
We have previously reported that aspirin induces apoptosis in manganese superoxide dismutase (MnSOD)-deficient Saccharomyces cerevisiae cells when cultivated on the non-fermentable carbon source ethanol. Here, we investigated the role of mitochondria in aspirin-induced apoptosis. We report that aspirin had an inhibitory effect on cellular respiration, and caused the release of most of the mitochondrial cytochrome $c$ and a dramatic drop in the mitochondrial membrane potential $\left(\Delta \Psi_{\mathrm{m}}\right)$. Also, aspirin reduced the intracellular cytosolic $\mathrm{pH}$ in the MnSODdeficient cells growing in ethanol medium, but this did not seem to be the initial trigger that committed these cells to aspirin-induced apoptosis. Furthermore, loss of $\Delta \Psi_{\mathrm{m}}$ was not required for aspirin-induced release of cytochrome $c$, since the initial release of cytochrome $c$ occurred prior to the disruption of the $\Delta \Psi_{\mathrm{m}}$. It is thus possible that cytochrome $c$ release does not involve the early onset of the mitochondrial permeability transition, but only an alteration of the permeability of the outer mitochondrial membrane.

\section{INTRODUCTION}

Non-steroidal anti-inflammatory drugs, principally aspirin, have anti-neoplastic properties, as shown by epidemiological studies on colorectal cancer (Kune et al., 1988; Chan et al., 2004). The chemopreventive and anti-proliferative properties of aspirin towards cell cultures and tumour cells have been shown to be due to the induction of apoptosis (Qiao et al., 1998; Pique et al., 2000). Several molecular mechanisms that underlie the apoptotic effect of aspirin have been reported, including p38 MAP kinase activation in human fibroblasts (Schwenger et al., 1998), inhibition of human telomerase reverse transcriptase in colon cancer cells (He et al., 2006), activation of caspases (Castano et al., 1999; Power et al., 2004), downregulation of the antiapoptotic Bcl-2 protein (Gao et al., 2004; Redlak et al., 2005) and alteration of the signalling pathway of the transcription factor NF- $\kappa \mathrm{B}$ in human gastric cells (Stark \& Dunlop, 2005). Moreover, aspirin enhances tumour apoptotic cell death by promoting the onset of the mitochondrial permeability transition (Uyemura et al., 1997; Oh et al., 2003).

Apoptosis in yeast cells is accompanied by typical features of mammalian apoptosis (Madeo et al., 1997) after treatment of the cells with low doses of hydrogen peroxide

Abbreviations: C-SNARF-1-AM, 5-(and-6-)-carboxy-seminaphthorhodafluor-1-acetoxymethyl ester; CuZnSOD, copper/zinc superoxide dismutase; FCCP, carbonylcyanide- $p$-trifluoromethoxyphenylhydrazone; $\Delta \Psi_{m}$, mitochondrial membrane potential; $\mathrm{MnSOD}$, manganese superoxide dismutase; NAO, 10- $\mathrm{N}$-nonyl acridine orange; $\mathrm{pH}_{\mathrm{i}}$, intracellular $\mathrm{pH}$; Rh123, rhodamine 123; ROS, reactive oxygen species.
(Madeo et al., 1999), $\alpha$ mating-type pheromone (Severin \& Hyman, 2002) and hyperosmotic stress (Silva et al., 2005). Also, orthologues of key regulators of mammalian apoptosis, such as the metacaspase Ycalp (Madeo et al., 2002), the serine protease HtrA2/Omi (Fahrenkrog et al., 2004), apoptosis-inducing factor (Aiflp) (Wissing et al., 2004) and mitochondrial endonuclease G (Nuclp) (Büttner et al., 2007) have been characterized in yeast, thus demonstrating the presence of a basic apoptotic machinery similar to that found in higher organisms. Furthermore, this model system has been used to probe the relation between apoptosis and mitochondrial fragmentation (Fannjiang et al., 2004), histone H2B phosphorylation (Ahn et al., 2005) and tBid/Bax-induced mitochondrial cytochrome $c$ release (Ott et al., 2007).

In previous work, we studied the effect of aspirin on Saccharomyces cerevisiae cells with differential protection against reactive oxygen species (ROS) and differential production of ROS, which was obtained with growth of wild-type and manganese superoxide dismutase (MnSOD)-deficient cells on fermentable and non-fermentable carbon sources. We showed that aspirin-treated MnSOD-deficient yeast cells died through a late apoptotic process when cultivated on the non-fermentable carbon source ethanol. Aspirin was found to act as an antioxidant until the appearance of apoptosis (Balzan et al., 2004). However, aspirin caused an early shift in the redox environment, due to depletion of NADPH and NADP ${ }^{+}$, which led to a dramatic drop in the GSH/GSSG concentration ratio (Sapienza \& Balzan, 2005). 
In the present work, we used the same experimental model of apoptosis and investigated the role of mitochondria in aspirin-induced apoptosis in the MnSOD-deficient yeast cells growing in ethanol medium, with a focus on cytochrome $c$ release and the effect of aspirin on the mitochondrial membrane potential $\left(\Delta \Psi_{\mathrm{m}}\right)$. We also studied the effect of aspirin on the intracellular cytosolic $\mathrm{pH}\left(\mathrm{pH}_{\mathrm{i}}\right)$ of these cells.

\section{METHODS}

Culture conditions and treatments. The parent $S$. cerevisiae strain

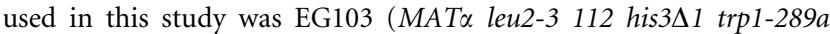
ura3-52 $G A L^{+}$) and the MnSOD-deficient strain was EG110 (EG103 $\operatorname{sod} 2 \Delta:$ :TRP1), kindly provided by Edith Gralla of University of California, Los Angeles, and Valeria C. Culotta of Johns Hopkins University. Cells were grown in enriched yeast extract, peptone-based medium with $3 \%(\mathrm{v} / \mathrm{v})$ ethanol. For plates, $2 \%(\mathrm{w} / \mathrm{v})$ agar was used and incubation was at $28{ }^{\circ} \mathrm{C}$. Aerobic growth in liquid culture was maintained at $28{ }^{\circ} \mathrm{C}$ with constant shaking at 250 r.p.m. The cells were also cultured in fresh media in the presence of $15 \mathrm{mM}$ aspirin (acetylsalicylic acid) (Sigma), and the $\mathrm{pH}$ of the medium was adjusted to 5.5 with $1 \mathrm{M}$ Trizma base (Sigma). Growth was followed by monitoring $\mathrm{OD}_{600}$. Cultures with $\mathrm{OD}_{600}$ values greater than 1.0 were diluted as necessary.

Oxygen consumption. The cellular oxygen consumption of yeast cells was measured polarographically, as described elsewhere (Longo et al., 1999), using a YSI Biological Oxygen Monitor (model 5300) and a Clark-type oxygen electrode. Briefly, yeast cells $\left(3.2 \times 10^{8}\right)$ were added to a sample chamber containing $4 \mathrm{ml}$ YPE medium, with or without $15 \mathrm{mM}$ aspirin, and were magnetically stirred at $30{ }^{\circ} \mathrm{C}$. In this way, the rate of oxygen consumption was measured under closely similar conditions to those found in the flask cultures. The oxygen consumption of the yeast cells was monitored after the addition of carbonylcyanide- $p$-trifluoromethoxyphenylhydrazone (FCCP) (Sigma) and potassium cyanide (KCN) (BDH) to the culture medium. Four micromolar FCCP accelerated respiration and $700 \mu \mathrm{M} \mathrm{KCN}$ inhibited respiration, as expected.

Isolation of mitochondria and Western blot analysis. Isolation of the yeast mitochondrial and membrane-free cytosolic fractions was carried out as described by Glick \& Pon (1995). Both the mitochondrial and cytosolic extracts were then aliquoted, flashfrozen and stored at $-80{ }^{\circ} \mathrm{C}$. Protein concentration was determined by the Bio-Rad assay (Bio-Rad Laboratories), using BSA as protein standard. For Western blot analysis, $10 \mu \mathrm{g}$ of protein from the mitochondrial fractions and $40 \mu \mathrm{g}$ of protein from the cytosolic fractions, obtained from aspirin-treated and untreated EG110 cells, were subjected to $15 \%(\mathrm{w} / \mathrm{v})$ SDS-PAGE and transferred overnight onto nitrocellulose membranes (Amersham International). Blots were blocked with $5 \%(\mathrm{w} / \mathrm{v})$ non-fat dried milk in Tris-buffered saline containing $0.1 \%$ Tween-20 (TBS-T) for $1 \mathrm{~h}$, washed thoroughly with TBS-T, and incubated with the following primary antibodies in TBS$\mathrm{T}$ for $1 \mathrm{~h}$ : anti-cytochrome $c$ (Davids Biotechnologie), anti-HSP60 (kindly provided by G. Schatz, Basel University) and anti- $\beta$-actin (Abcam). This was followed by incubation with horseradish peroxidase-labelled secondary antibody, and the immunoreactive bands were detected by enhanced chemiluminescence (ECL Western blotting detection kit, Amersham Biosciences).

Measurement of $\Delta \Psi_{\mathrm{m}}$ and mitochondrial mass. The $\Delta \Psi_{\mathrm{m}}$ of yeast cells was determined as described elsewhere (Ludovico et al., 2001), utilizing the fluorescent probe rhodamine 123 (Rh123)
(Molecular Probes). Yeast cells $\left(1 \times 10^{6}\right)$ were harvested, suspended in $1 \mathrm{ml}$ distilled water ( $\mathrm{pH}$ 6.0) and incubated in $200 \mathrm{nM}$ Rh123 for $30 \mathrm{~min}$ at room temperature. The cells were recovered, resuspended in $400 \mu \mathrm{l}$ distilled water and analysed on the Bio-Rad BRYTE HS flow cytometer. As a positive control, cells were treated with $20 \mathrm{mM}$ sodium azide (Sigma) prior to staining with Rh123. The green fluorescence was gated in a scattergram of $\log (\mathrm{SS})$ (side scatter) $-\log$ (FS) (forward scatter) in order to include the subpopulation with the highest frequency and homogeneity in the fluorescence measurement. Mitochondrial mass was detected using 10- $N$-nonyl acridine orange (NAO) (Molecular Probes), as described elsewhere (Massari et al., 2000). Cells $\left(1 \times 10^{6}\right)$ obtained from the same cell cultures used to measure $\Delta \Psi_{\mathrm{m}}$ were harvested, washed with sterile distilled water and fixed with ice-cold $80 \%(\mathrm{v} / \mathrm{v})$ ethanol at $-20{ }^{\circ} \mathrm{C}$ overnight. The cells were recovered, washed twice in distilled water and incubated in $10 \mu \mathrm{M}$ NAO for $30 \mathrm{~min}$ at room temperature. The cells were resuspended in $400 \mu \mathrm{l}$ sterile distilled water and FACS analysis was carried out using a Bio-Rad BRYTE HS flow cytometer.

Measurement of intracellular and extracellular pH. $\mathrm{pH}_{\mathrm{i}}$ was measured using the ratiometric dye 5-(and-6-)-carboxy-seminaphthorhodafluor-1-acetoxymethyl ester (C-SNARF-1-AM) (Molecular Probes), as described by Haworth et al. (1991), with some modifications. Yeast cells $\left(1 \times 10^{8} \mathrm{ml}^{-1}\right)$ were harvested and incubated with $20 \mu \mathrm{M}$ C-SNARF-1-AM in $0.2 \mathrm{M}$ Tris-acetate, $\mathrm{pH}$ 5.0, for $3 \mathrm{~h}$ at $21{ }^{\circ} \mathrm{C}$. An in vivo calibration curve was prepared by suspending the CSNARF-1-AM-loaded cells in $0.2 \mathrm{M}$ acetic acid-Tris/Tris-acetate buffers, over the $\mathrm{pH}$ range 4.0-10.0. The cells were then incubated with $30 \mu \mathrm{M}$ amphotericin $\mathrm{B}$ (Sigma) at $30{ }^{\circ} \mathrm{C}$ for $1 \mathrm{~h}$, so that the $\mathrm{pH}_{\mathrm{i}}$ equilibrated with the extracellular $\mathrm{pH}$. The fluorescence of C-SNARF1-AM was detected using a Bio-Tek Instruments fluorometer with excitation at $514 \mathrm{~nm}$ and emission at $575 \mathrm{~nm}$ and $610 \mathrm{~nm}$.

For purposes of calibration, the ratio, $R$, of fluorescence emission at 575 and $610 \mathrm{~nm}$, after background subtraction, was determined at unit $\mathrm{pH}$ intervals. The Henderson-Hasselbalch equation:

$\mathrm{pH}=\mathrm{pK}^{\prime}+\log \left[\left(R_{\mathrm{a}}-R\right) /\left(R-R_{\mathrm{b}}\right)\right]$

was used to determine the intracellular $\mathrm{pH} . R_{\mathrm{a}}$ and $R_{\mathrm{b}}$ represent the limiting values of the ratio at acidic and basic $\mathrm{pH}$, respectively, and $\mathrm{pK}^{\prime}$ represents the apparent $\mathrm{pK}$ for dissociation of the probe in the intracellular environment. In each experiment, the values of $R_{\mathrm{a}}, R_{\mathrm{b}}$ and $\mathrm{pK}^{\prime}$ were determined by fitting the data to the equation,

$R=R_{\mathrm{a}}-\left(R_{\mathrm{a}}-R_{\mathrm{b}}\right) /\left(1+10^{\mathrm{pK}^{\prime}-\mathrm{pH}}\right)$

by Marquardt's method of nonlinear least-squares with uniform weights (Press et al., 1996). The basis of this equation is discussed in Opitz et al. (1994). Both test ratios and calibration curves showed appreciable experimental variation in each set of incubation conditions. Because of this variation, replicates of the predicted values of the $\mathrm{pH}_{\mathrm{i}}$ were pooled, and a $25 \%$ trimmed mean of the data was taken as a measure of the best mean $\mathrm{pH}$.

The extracellular $\mathrm{pH}$ of the cell cultures was measured with a PHM 83 AUTOCAL pH meter (Radiometer).

\section{RESULTS}

\section{Cellular growth and respiration is dramatically reduced in aspirin-treated MnSOD-deficient S. cerevisiae cells in ethanol medium}

MnSOD-deficient EG110 cells cultivated in YPE medium in the presence of $15 \mathrm{mM}$ aspirin showed the pattern of growth described previously for cells undergoing apoptosis 
(Balzan et al., 2004). The cells ceased to grow after $48 \mathrm{~h}$, and at $96 \mathrm{~h}$ cultivation the $\mathrm{OD}_{600}$ of the cultures was only $10 \%$ of that of control cells.

The ability of $S$. cerevisiae strains EG103 [containing both MnSOD and copper/zinc superoxide dismutase (CuZnSOD)] and EG110 (deficient in MnSOD) to respire on the nonfermentable carbon source ethanol, in the absence and presence of $15 \mathrm{mM}$ aspirin, was assayed polarographically (Fig. 1). The rate of respiration in EG110 cells was maintained at $\sim 29 \mathrm{nmol} \mathrm{O}_{2} \mathrm{~min}^{-1}$ per $10^{7}$ cells $( \pm 2.4 \mathrm{sD})$ during the different stages of growth. Similarly, respiration in EG103 cells was $28 \mathrm{nmol} \mathrm{O}_{2} \mathrm{~min}^{-1}$ per $10^{7}$ cells $( \pm 2.4 \mathrm{sD})$ until $72 \mathrm{~h}$ of growth, and decreased to $20.1 \mathrm{nmol} \mathrm{O}_{2} \mathrm{~min}^{-1}$ per $10^{7}$ cells $( \pm 3.3 \mathrm{SD})$ after $96 \mathrm{~h}$ of growth. The decrease in respiration observed in wild-type EG103 cells may be accounted for by the fact that the cells reach stationary phase before MnSODdeficient EG110 cells. Upon treatment with aspirin, respiration in EG110 cells decreased ninefold after $48 \mathrm{~h}$ of cultivation, as compared with untreated EG110 cells, and the rate of respiration decreased further after 72 and $96 \mathrm{~h}$ of

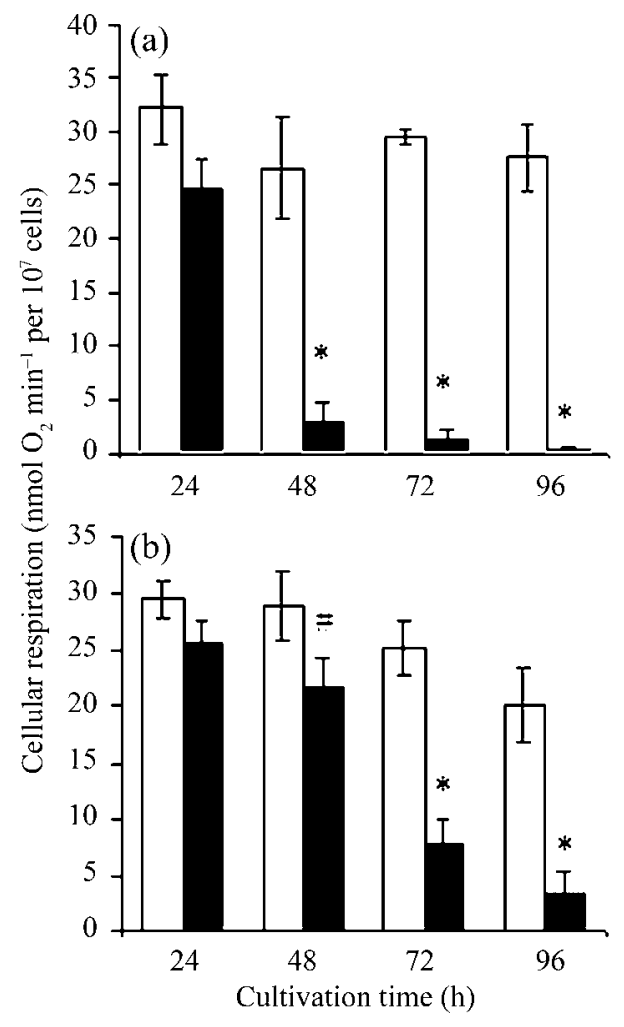

Fig. 1. Cellular respiration of (a) S. cerevisiae EG110 cells (deficient in MnSOD) and (b) EG103 cells (containing both MnSOD and CuZnSOD) growing in YPE medium without aspirin (open bars) and in the presence of $15 \mathrm{mM}$ aspirin (solid bars). Oxygen consumption was monitored using a Clark-type electrode. Each point represents the mean of at least four independent determinations. Error bars represent $\pm 1 \mathrm{SD}$ and appear where sufficiently large. ${ }^{*} P<0.001 ; \# P<0.01$; treatment versus control, two-tailed $t$ test. growth (Fig. 1a). Aspirin also had an inhibitory effect on respiration in EG103 cells; however, after $48 \mathrm{~h}$ of cultivation there was a 1.3 -fold decrease in respiration. The rate of respiration in aspirin-treated EG103 cells after $96 \mathrm{~h}$ of cultivation was higher than in aspirin-treated EG110 cells after $48 \mathrm{~h}$ of growth (Fig. 1b). Thus, aspirin has a severe inhibitory effect on mitochondrial respiration, as reflected in cellular respiration in MnSOD-deficient cells when grown in ethanol medium, and a less severe inhibitory effect on mitochondrial respiration in wild-type cells.

\section{Aspirin induces mitochondrial cytochrome $c$ release in MnSOD-deficient cells in ethanol medium}

Next, we examined whether cytochrome $c$ plays a role in aspirin-induced apoptosis in MnSOD-deficient cells. The levels of cytochrome $c$ in mitochondria and in the cytosol from aspirin-treated EG110 cells was detected by Western blot analysis and immunoscreening. After $48 \mathrm{~h}$ of growth in YPE medium, the level of mitochondrial cytochrome $c$ in EG110 cells treated with $15 \mathrm{mM}$ aspirin was similar to that detected in untreated control cells (Fig. 2b, c). However, after $72 \mathrm{~h}$ of cultivation, there was a slight decrease in the level of mitochondrial cytochrome $c$, and, after $96 \mathrm{~h}$, a dramatic decrease in the level of mitochondrial cytochrome $c$ was observed (Fig. 2c). The cytochrome $c$ released from the mitochondria was detected in the cytosolic fractions (Fig. 2d). In fact, after $48 \mathrm{~h}$ of cultivation no cytochrome $c$ was detected in the cytosol; however, the levels of cytochrome $c$ in the cytosol increased after 72 and $96 \mathrm{~h}$ of cultivation (Fig. 2d). No cytochrome $c$ was detected in the cytosol of untreated control cells (data not shown). HSP60 was not detected in the cytosolic fractions of EG110 cells untreated and treated with aspirin, indicating that there was no mitochondrial contamination in the cytosol (data not shown). $\beta$-Actin was not detected in the mitochondrial fractions, indicating that there was no mitochondrial contamination from the cytosolic fractions (data not shown). Thus, these findings demonstrate that cytochrome $c$ is translocated from mitochondria into the cytosol during aspirin-induced apoptosis.

\section{Aspirin causes a drastic fall in the mitochondrial membrane potential of MnSOD-deficient cells and this occurs after the release of cytochrome $c$}

We then asked whether onset of the mitochondrial permeability transition and loss of $\Delta \Psi_{\mathrm{m}}$ were required for the translocation of mitochondrial cytochrome $c$ to the cytosol. We examined whether the $\Delta \Psi_{\mathrm{m}}$ and mitochondrial mass of aspirin-treated and -untreated EG110 cells growing in YPE medium were altered by carrying out FACS analysis of Rh123- and NAO-stained cells, respectively. The relative fluorescence emission in Rh123-stained EG110 cells was similar to that detected in wild-type EG103 cells, which had a relative fluorescence emission of $41.1 \pm 2.11$ and $41.4 \pm 3.01$ after 72 and $96 \mathrm{~h}$ of growth, respectively. In aspirin-treated EG110 cells, the relative fluorescence emis- 


\section{Time (h) \\ $48 \quad 72 \quad 96$}

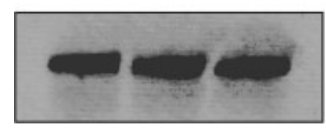

(a) Mitochondrial HSP60 from cells treated with aspirin

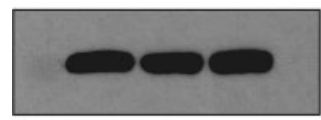

(b) Mitochondrial cytochrome $c$ from cells not treated with aspirin

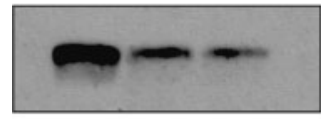

(c) Mitochondrial cytochrome $c$ from cells treated with aspirin

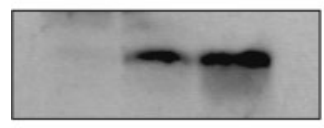

(d) Cytochrome $c$ in cytosol from cells treated with aspirin

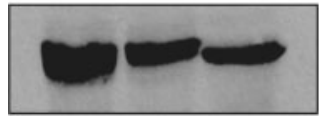

(e) $\beta$-Actin in cytosol of cells treated with aspirin

Fig. 2. Cytochrome $c$ is released from mitochondria into the cytosol during aspirin-induced apoptosis in MnSOD-deficient $S$. cerevisiae EG110 cells growing in YPE medium. Cytochrome $c$ was detected by Western blot analysis and immunoscreening of the mitochondrial and cytosolic fractions, obtained from EG110 cells cultivated in YPE medium, with and without $15 \mathrm{mM}$ aspirin. An equal amount of total mitochondrial protein was loaded in each lane, as demonstrated (a) by HSP60 concentration in the mitochondrial fractions. (b) The level of mitochondrial cytochrome $c$ in EG110 cells, not treated with aspirin, was the same after 48, 72 and $96 \mathrm{~h}$ of growth. (c) The level of mitochondrial cytochrome $c$ decreased in aspirin-treated EG110 cells, after 72 and $96 \mathrm{~h}$ of growth. (d) Cytochrome $c$ was detected in the cytosol after $72 \mathrm{~h}$. After $96 \mathrm{~h}$, most of the mitochondrial cytochrome $c$ was present in the cytosol. (e) $\beta$-Actin concentration in the cytosolic fractions. The data represent at least three independent experiments.

sion was similar to that of untreated control cells after 48 and $72 \mathrm{~h}$ of cultivation. However, after $96 \mathrm{~h}$ of cultivation there was a drastic fall in the relative fluorescence emission from $39.2 \pm 1.62$ to $20.3 \pm 0.62$ (Fig. 3). In fact, the $\Delta \Psi_{\mathrm{m}}$ in aspirin-treated MnSOD-deficient cells decreased to nearly half that of untreated EG110 cells.

The mitochondrial mass in aspirin-treated EG110 cells displayed fluorescence comparable to that of untreated control cells. After $48 \mathrm{~h}$ of cultivation, the relative fluorescence emission of EG110 cells was $130.6 \pm 3.89$ and $130.7 \pm 4.20$ in the absence and presence of aspirin, respectively. After $72 \mathrm{~h}$ of growth, the relative fluorescence emission increased to $144.8 \pm 4.26$ and $141.0 \pm 3.26$, in the absence and presence of aspirin, respectively, and this remained the same after $96 \mathrm{~h}$ of growth. Thus, the mitochondrial mass of aspirin-treated MnSOD-deficient cells was similar to that of untreated cells, indicating that the

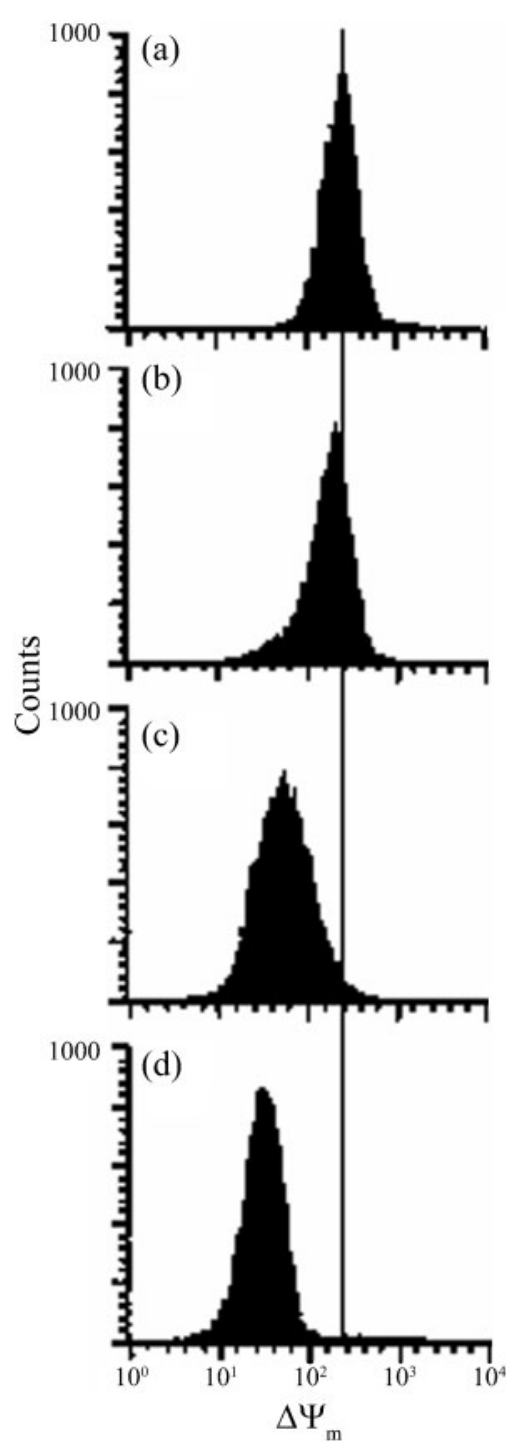

Fig. 3. Disruption of $\Delta \Psi_{\mathrm{m}}$ in aspirin-treated S. cerevisiae EG110 cells (deficient in MnSOD). EG110 cells were cultivated in YPE medium in the presence of $15 \mathrm{mM}$ aspirin, $\mathrm{pH}$ 5.5, and stained with Rh123 after (a) 48 h, (b) $72 \mathrm{~h}$ and (c) $96 \mathrm{~h}$ of cultivation. (d) As a positive control, aspirin-treated EG110 cells were treated with $20 \mathrm{mM}$ sodium azide (to disrupt the mitochondrial electron transport chain), prior to Rh123 staining. FACS analysis was used and the data represent at least three independent experiments. Data are represented as cell number (Counts) versus relative fluorescence emission $\left(\Delta \Psi_{\mathrm{m}}\right)$. Approximately 20000 cells were analysed for each sample.

drastic fall in the $\Delta \Psi_{\mathrm{m}}$ of aspirin-treated cells after $96 \mathrm{~h}$ of cultivation was not due to a decrease in mitochondrial mass.

\section{MnSOD-deficient cells are unable to maintain intracellular pH in YPE medium in the presence of aspirin}

The maintenance of cytoplasmic $\mathrm{pH}$ is crucial for many enzyme activities and for cellular metabolism, and we next 
assessed whether aspirin altered the intracellular $\mathrm{pH}$, thereby committing MnSOD-deficient cells to apoptosis. The $\mathrm{pH}_{\mathrm{i}}$ in the MnSOD-deficient EG110 cells in YPE medium was maintained at $\sim \mathrm{pH} 7.2$ during the different phases of growth (Fig. 4a). Aspirin-treated EG110 cells also maintained a $\mathrm{pH}_{\mathrm{i}}$ of 7.2 after 48 and $72 \mathrm{~h}$ of cultivation. However, after $96 \mathrm{~h}$ of growth there was a drop to $\mathrm{pH}_{\mathrm{i}} 6.5$. Statistical analysis of the data showed a significant difference in intracellular $\mathrm{pH}(P<0.001)$ between aspirintreated and untreated cells after $96 \mathrm{~h}$ of cultivation ( $t$ test; see Fig. 4a). This finding indicated that the cells were unable to regulate the cytosolic $\mathrm{pH}$ when treated with aspirin. Changes in the external $\mathrm{pH}$ of the cell culture corresponded with loss of cellular ability to regulate the cytosolic $\mathrm{pH}$. In fact, the external $\mathrm{pH}$ of YPE medium harbouring EG110 cells with or without $15 \mathrm{mM}$ aspirin

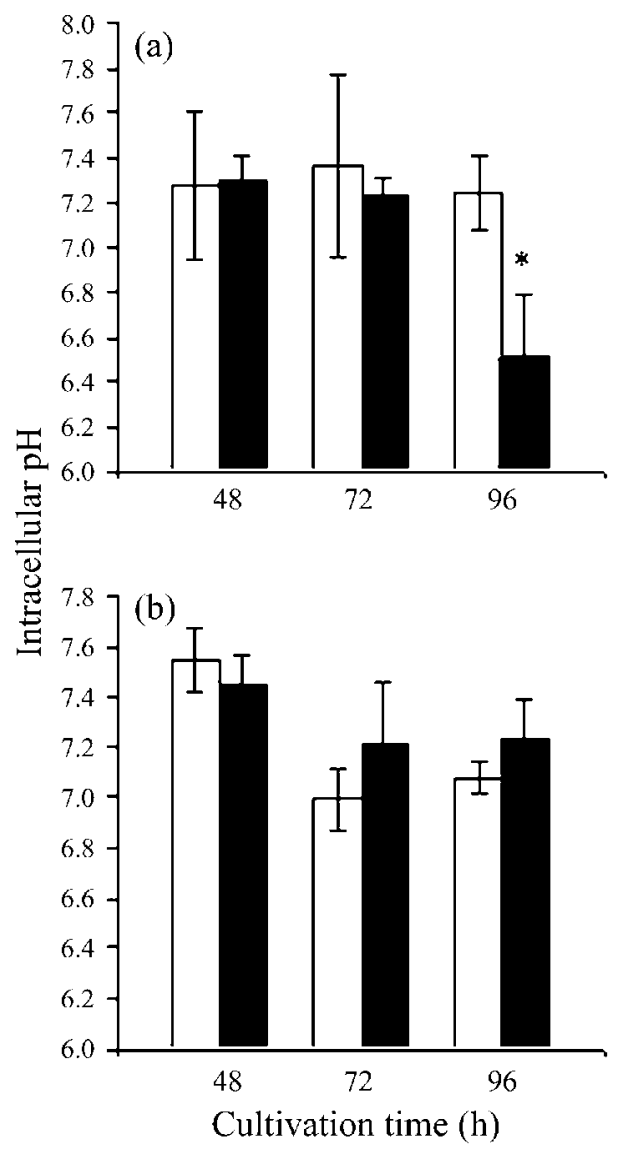

Fig. 4. Intracellular $\mathrm{pH}$ of (a) S. cerevisiae EG110 cells (deficient in MnSOD) and (b) EG103 cells (containing both MnSOD and CuZnSOD) growing in YPE medium without aspirin (open bars) and in the presence of $15 \mathrm{mM}$ aspirin (solid bars). The ratiometric fluorescent dye C-SNARF-1-AM was used. The emission spectra were measured at 575 and $610 \mathrm{~nm}$, with excitation at $514 \mathrm{~nm}$. Background fluorescence was subtracted from the data. Each point represents the mean of at least four independent determinations. Error bars, $\pm 1 \mathrm{SD}$; ${ }^{*} P<0.001$; treatment versus control, twotailed $t$ test. was initially 5.5 , but dropped to 4.95 and 4.88 , respectively, after $48 \mathrm{~h}$ of cultivation. At $72 \mathrm{~h}$ of cultivation, the extracellular $\mathrm{pH}$ of EG110 cells treated with aspirin decreased to $\mathrm{pH} 4.6$, and remained the same after $96 \mathrm{~h}$ of cultivation. However, the external pH of EG110 cells cultured without aspirin decreased significantly to $\mathrm{pH} 4.35$ $(P<0.05 ; t$ test $)$. There was no significant difference in the $\mathrm{pH}_{\mathrm{i}}$ of wild-type EG103 cells in YPE medium with or without aspirin (Fig. 4b). It appears that wild-type cells are able to maintain the $\mathrm{pH}_{\mathrm{i}}$ above $\mathrm{pH} 7.0$ throughout the different phases of growth, even in the presence of $15 \mathrm{mM}$ aspirin, whereas aspirin-treated MnSOD-deficient cells are unable to maintain a homeostatic cytosolic $\mathrm{pH}$.

\section{DISCUSSION}

Our data showed that aspirin inhibits cellular respiration in MnSOD-deficient $S$. cerevisiae cells when cultivated on the non-fermentable carbon source ethanol. The pronounced fall in the rate of respiration was seen after $48 \mathrm{~h}$ of growth (Fig. 1a), when the MnSOD-deficient cells were still viable, as measured by the ability to form new colonies. Afterwards these cells undergo a drastic fall in viability in the presence of aspirin (Balzan et al., 2004), which correlates with the observed decrease in respiration. Aspirin also had an inhibitory effect on cellular respiration in wild-type cells (Fig. 1b); however, this was not so severe and did not effect cellular growth or viability (data not shown). Aspirin has been reported to uncouple oxidative phosphorylation in isolated rat liver mitochondria when present in micromolar concentrations (Adams \& Cobb, 1958; Somasundaram et al., 1997); however, low millimolar concentrations of aspirin inhibit mitochondrial respiration in isolated rat liver (Somasundaram et al., 1997) and cardiac mitochondria (Nulton-Persson et al., 2004). The inhibitory effect of aspirin on respiration is due to inhibition of the electron transport chain (at complex I and complex II) in isolated rat liver mitochondria (Somasundaram et al., 1997). Nulton-Persson et al. (2004) reported that aspirin limits the supply of NADH to the electron transport chain through inhibition of $\alpha$ ketoglutarate dehydrogenase in isolated rat cardiac mitochondria. We have previously shown that aspirin significantly decreases the levels of $\mathrm{NADP}^{+}$and NADPH in MnSOD-deficient yeast cells after $72 \mathrm{~h}$ of cultivation in ethanol medium (Sapienza \& Balzan, 2005).

The role of cytochrome $c$ in aspirin-induced apoptosis in the MnSOD-deficient cells was investigated next, since cytochrome $c$ plays a central role in the generation of downstream apoptotic events in mammalian cells (Li et al., 1997). An initial release of cytochrome $c$ was detected in the cytosol of aspirin-treated MnSOD-deficient cells, at which time aspirin had no effect on $\Delta \Psi_{\mathrm{m}}$ (Figs 2 and 3). However, after $96 \mathrm{~h}$ of cultivation, most of the mitochondrial cytochrome $c$ was detected in the cytosol, and this correlated with a dramatic drop in $\Delta \Psi_{\mathrm{m}}$, which decreased to nearly half that of untreated control cells. The results 
confirm our previous finding that aspirin induces apoptosis in the MnSOD-deficient cells grown in ethanol medium (Balzan et al., 2004), with the same time order of apoptosis-related events. Also, the findings are consistent with the results of Pique et al. (2000), whereby aspirin induces apoptosis through mitochondrial cytochrome $c$ release prior to caspase activation and loss of $\Delta \Psi_{\mathrm{m}}$ in Jurkat and acute T-leukaemia cell lines. Indeed, the participation of cytochrome $c$ in yeast apoptosis has been suggested, since mutations in cytochrome $c$ haem lyase partially rescue acetic acid-induced cell death (Ludovico et al., 2002) and yeast mutants lacking $c$-type cytochromes survive after treatment with $\alpha$-factor and amiodarone (Pozniakovsky et al., 2005).

Our observations demonstrate that loss of $\Delta \Psi_{\mathrm{m}}$ is not required for aspirin-induced release of cytochrome $c$. In fact, the initial release of cytochrome $c$ occurred prior to the disruption of the $\Delta \Psi_{\mathrm{m}}$. It is thus possible that cytochrome $c$ release does not involve the early onset of the mitochondrial permeability transition but only an alteration of the permeability of the outer mitochondrial membrane. Other studies support this, inasmuch as the mitochondrial inner membrane remains intact even under circumstances in which cytochrome $c$ has been released (Priault et al., 1999; Waterhouse et al., 2001).

Expression of Bax in S. cerevisiae, as well as treatment of yeast cells with acetic acid, amiodarone and $\alpha$-factor, induces a transient increase in the mitochondrial membrane potential, causing mitochondrial ROS formation, followed by depolarization and cell death (Manon et al., 1997; Ludovico et al., 2002; Pozniakovsky et al., 2005). We detected a fall in the $\Delta \Psi_{\mathrm{m}}$ at $96 \mathrm{~h}$ of cultivation (Fig. 3), at which time the antioxidant effect of aspirin was at its highest (Balzan et al., 2004). Votyakova \& Reynolds (2001) have also shown that depolarization of rat brain mitochondria causes a profound reduction in ROS formation. Indeed, Starkov \& Fiskum (2003) have demonstrated that ROS production is influenced by $\Delta \Psi_{\mathrm{m}}$ and the $\mathrm{NAD}(\mathrm{P}) \mathrm{H}$ redox state in isolated brain mitochondria, in which a reduction in $\Delta \Psi_{\mathrm{m}}$ is accompanied by a decrease in $\mathrm{H}_{2} \mathrm{O}_{2}$ production in the presence of NADH-linked oxidizable substrates.

Maintenance of a homeostatic $\mathrm{pH}_{\mathrm{i}}$ is also essential for the proper functioning of enzymes. In fact, the $\mathrm{pH}_{\mathrm{i}}$ in mammalian cells is maintained around neutrality in order to sustain metabolic pathways (Madshus, 1988). In our study, the mean $\mathrm{pH}_{\mathrm{i}}$ of MnSOD-deficient cells cultivated in ethanol medium was 7.2 during the different phases of growth, and that in wild-type cells was maintained above 7.0 (Fig. 4a, b). These results agree to some extent with those of other reports. The $\mathrm{pH}_{\mathrm{i}}$ of a respiratory-deficient S. cerevisiae mutant, IGC3507 III, measured by the distribution of $\left[{ }^{14} \mathrm{C}\right]$ propionic acid, was found to be between 7.0 and 7.2 (Pampulha \& Loureiro-Dias, 1989). The mean resting internal $\mathrm{pH}$ was 6.6 in S. cerevisiae and 7.0 in Schizosaccharomyces pombe, measured using the fluorescent probe C-SNARF-1 (Haworth \& Fliegel, 1993).
Although the MnSOD-deficient cells maintained the $\mathrm{pH}_{\mathrm{i}}$ at 7.2 after $72 \mathrm{~h}$ of cultivation in the presence of aspirin, after $96 \mathrm{~h}$ of cultivation, the $\mathrm{pH}_{\mathrm{i}}$ fell to 6.5 , which is $0.7 \mathrm{pH}$ units lower than in control cells (Fig. 4a). These findings indicate that the MnSOD-deficient cells were unable to maintain the homeostatic cytosolic $\mathrm{pH}$. A decrease in $\mathrm{pH}_{\mathrm{i}}$ of $\sim 0.3-$ 0.4 units has been detected elsewhere following exposure of mammalian cells to several apoptotic triggers, including UV irradiation, staurosporine, anti-Fas antibodies and growth-factor deprivation (reviewed by Matsuyama \& Reed, 2000). An early decrease in the cytosolic pH was detected after treatment of Jurkat cells with the kinase inhibitor staurosporine. Our results suggest that the imbalance in $\mathrm{pH}_{\mathrm{i}}$ regulation, as reflected by the fall in the cytosolic $\mathrm{pH}$ of aspirin-treated MnSOD-deficient cells, may reflect compromised energy stores and commitment to apoptosis. Several reports show that the mechanism of $\mathrm{pH}$ homeostasis is dependent on the presence of an energy source (Karagiannis \& Young, 2001; Piper et al., 2001). However, the fall in $\mathrm{pH}_{\mathrm{i}}$ in the MnSOD-deficient strain does not seem to be the initial trigger that commits these cells to apoptosis, since it occurred only after $96 \mathrm{~h}$ of cultivation, when the cells would have already lost their viability.

Our findings suggest that inhibition of aerobic respiration in the presence of aspirin is linked to the development of apoptosis in MnSOD-deficient yeast cells grown on ethanol medium, without implying direct causation. Additionally, this inhibitory effect of aspirin may account for the low ROS levels detected in the yeast cells (Balzan et al., 2004). The presence of MnSOD in isogenic wildtype cells seems to have a protective effect on mitochondria, since aerobic respiration is not inhibited as extensively as in MnSOD-deficient cells. A protective effect of MnSOD on complexes I and III of the respiratory chain has been observed in 32D cl 3 haematopoietic cells overexpressing a human MnSOD (SOD2) transgene when exposed to radiation (Pearce et al., 2001). In our work, inhibition of aerobic respiration and concomitant redox imbalance (Sapienza \& Balzan, 2005) precede apoptotic induction. This possibly caused the initial release of mitochondrial cytochrome $c$, followed by disruption of the $\Delta \Psi_{\mathrm{m}}$, further release of nearly all the mitochondrial cytochrome $c$ and concomitant decrease in $\mathrm{pH}_{\mathrm{i}}$. Fig. 5 summarizes the sequence of events observed to lead to apoptosis. We propose to investigate the mitochondrial origin of the apoptotic process and its relationship to inhibition of aerobic respiration on ethanol medium by cloning and targeting of exogenous MnSOD to the mitochondria of the yeast cells.

\section{AKCNOWLEDGEMENTS}

We are grateful to Professor Alex Felice for the use of the flow cytometer and Ms Wilma Cassar for technical advice on flow cytometry. This work was supported by a Research Fund Grant from the University of Malta. 


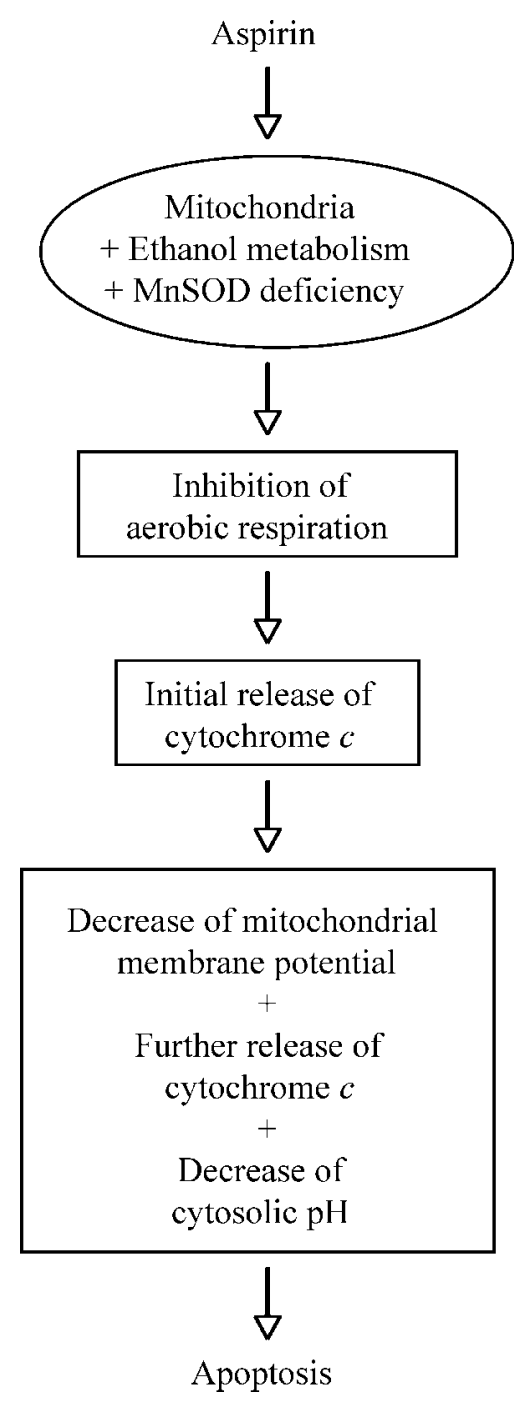

Fig. 5. Sequence of events associated with apoptosis in MnSODdeficient yeast cells grown on ethanol medium in the presence of aspirin. Inhibition of aerobic respiration occurred at $48 \mathrm{~h}$ of cultivation when the cells were still viable. Apoptosis was preceded by loss of viability and occurred after $96 \mathrm{~h}$ of cultivation. The initial release of mitochondrial cytochrome $c$ may be due to an alteration of the permeability of the outer mitochondrial membrane rather than onset of the mitochondrial permeability transition (MPT), because it occurs before the decrease in the $\Delta \Psi_{\mathrm{m}}$. MPT may occur afterwards when there is a decrease of $\Delta \Psi_{m}$ and further release of cytochrome $c$. Decrease of the intracellular cytosolic $\mathrm{pH}$ also occurs at the same time.

\section{REFERENCES}

Adams, S. S. \& Cobb, R. (1958). A possible basis for the antiinflammatory activity of salicylates and other non-hormonal antirheumatic drugs. Nature 181, 773-774.

Ahn, S. H., Cheung, W. L., Hsu, J. Y., Diaz, R. L., Smith, M. M. \& Allis, C. D. (2005). Sterile 20 kinase phosphorylates histone H2B at serine 10 during hydrogen peroxide-induced apoptosis in S. cerevisiae. Cell 120, $25-36$.
Balzan, R., Sapienza, K., Galea, D. R., Vassallo, N., Frey, H. \& Bannister, W. H. (2004). Aspirin commits yeast cells to apoptosis depending on carbon source. Microbiology 150, 109-115.

Büttner, S., Eisenberg, T., Carmona-Gutierrez, D., Ruli, D., Knauer, H., Ruckenstuhl, C., Sigrist, C., Wissing, S., Kollroser, M. \& other authors (2007). Endonuclease G regulates budding yeast life and death. Mol Cell 25, 233-246.

Castano, E., Dalmau, M., Barragan, M., Pueyo, G., Bartrons, R. \& Gil, J. (1999). Aspirin induces cell death and caspase-dependent phosphatidylserine externalization in HT-29 human colon adenocarcinoma cells. Br J Cancer 81, 294-299.

Chan, A. T., Giovannucci, E. L., Schernhammer, E. S., Colditz, G. A., Hunter, D. J., Willett, W. C. \& Fuch, C. S. (2004). A prospective study of aspirin use and the risk for colorectal adenoma. Ann Intern Med 140, 157-166.

Fahrenkrog, B., Sauder, U. \& Aebi, U. (2004). The S. cerevisiae HtrAlike protein Nma111p is a nuclear serine protease that mediates yeast apoptosis. J Cell Sci 117, 115-126.

Fannjiang, Y., Cheng, W. C., Lee, S. J., Qi, B., Pevsner, J., McCaffery, J. M., Hill, R. B., Basanez, G. \& Hardwick, J. M. (2004). Mitochondrial fission proteins regulate programmed cell death in yeast. Genes Dev 18, 2785-2797.

Gao, J., Niwa, K., Sun, W., Takemura, M., Lian, Z., Onogi, K., Seishima, M., Mori, H. \& Tamaya, T. (2004). Non-steroidal antiinflammatory drugs inhibit cellular proliferation and up-regulate cyclooxygenase- 2 protein expression in endometrial cancer cells. Cancer Sci 95, 901-907.

Glick, B. S. \& Pon, L. A. (1995). Isolation of highly purified mitochondria from Saccharomyces cerevisiae. Methods Enzymol 260, 213-223.

Haworth, R. S. \& Fliegel, L. (1993). Intracellular $\mathrm{pH}$ in Schizosaccharomyces pombe - comparison with Saccharomyces cerevisiae. Mol Cell Biochem 124, 131-140.

Haworth, R. S., Lemire, B. D., Crandall, D., Cragoe, E. J., Jr \& Fliegel, L. (1991). Characterisation of proton fluxes across the cytoplasmic membrane of the yeast Saccharomyces cerevisiae. Biochim Biophys Acta 1098, 79-89.

He, H., Xia, H. H., Wang, J. D., Gu, Q., Lin, M. C., Zou, B., Lam, S. K., Chan, A. O., Yuen, M. F. \& other authors (2006). Inhibition of human telomerase reverse transcriptase by nonsteroidal antiinflammatory drugs in colon carcinoma. Cancer 106, 1243-1249.

Karagiannis, J. \& Young, P. G. (2001). Intracellular pH homeostasis during cell-cycle progression and growth state transition in Schizosaccharomyces pombe. J Cell Sci 114, 2929-2941.

Kune, G. A., Kune, S. \& Watson, L. F. (1988). Colorectal cancer risk, chronic illnesses, operations, and medications: case control results from the Melbourne Colorectal Cancer Study. Cancer Res 48, 4399-4404.

Li, P., Nijhawan, D., Budihardjo, I., Srinivasula, S. M., Ahmad, M., Alnemri, E. S. \& Wang, X. (1997). Cytochrome $c$ and dATP-dependent formation of Apaf-1/caspase-9 complex initiates an apoptotic protease cascade. Cell 91, 479-489.

Longo, V. D., Liou, L. L., Valentine, J. S. \& Gralla, E. B. (1999). Mitochondrial superoxide decreases yeast survival in stationary phase. Arch Biochem Biophys 365, 131-142.

Ludovico, P., Sansonetty, F. \& Côrte-Real, M. (2001). Assessment of mitochondrial membrane potential in yeast cell populations by flow cytometry. Microbiology 147, 3335-3343.

Ludovico, P., Rodrigues, F., Almeida, A., Silva, M. T., Barrientos, A. \& Côrte-Real, M. (2002). Cytochrome $c$ release and mitochondria involvement in programmed cell death induced by acetic acid in Saccharomyces cerevisiae. Mol Biol Cell 13, 2598-2606. 
Madeo, F., Frohlich, E. \& Frohlich, K.-U. (1997). A yeast mutant showing diagnostic markers of early and late apoptosis. J Cell Biol 139, 729-734.

Madeo, F., Frohlich, E., Ligr, M., Grey, M., Sigrist, S. J., Wolf, D. H. \& Frohlich, K.-U. (1999). Oxygen stress: a regulator of apoptosis in yeast. J Cell Biol 145, 757-767.

Madeo, F., Herker, E., Maldener, C., Wissing, S., Lächelt, S., Herlan, M., Fehr, M., Lauber, K., Sigrist, S. J. \& other authors (2002). A caspaserelated protease regulates apoptosis in yeast. Mol Cell 9, 911-917.

Madshus, I. H. (1988). Regulation of intracellular $\mathrm{pH}$ in eukaryotic cells. Biochem J 250, 1-8.

Manon, S., Chaudhuri, B. \& Guerin, M. (1997). Release of cytochrome $c$ and decrease of cytochrome $c$ oxidase in Bax-expressing yeast cells, and prevention of these effects by coexpression of Bcl- $\mathrm{x}_{\mathrm{L}}$. FEBS Lett 415, 29-32.

Massari, P., Ho, Y. \& Wetzler, L. M. (2000). Neisseria meningitidis porin PorB interacts with mitochondria and protects cells from apoptosis. Proc Natl Acad Sci U S A 97, 9070-9075.

Matsuyama, S. \& Reed, J. C. (2000). Mitochondria-dependent apoptosis and cellular $\mathrm{pH}$ regulation. Cell Death Differ 7, 1155-1165.

Nulton-Persson, A. C., Szweda, L. I. \& Sadek, H. A. (2004). Inhibition of cardiac mitochondrial respiration by salicylic acid and acetylsalicylate. J Cardiovasc Pharmacol 44, 591-595.

Oh, K. W., Qian, T., Brenner, D. A. \& Lemasters, J. J. (2003). Salicylate enhances necrosis and apoptosis mediated by the mitochondrial permeability transition. Toxicol Sci 73, 44-52.

Opitz, N., Merten, E. \& Acker, H. (1994). Evidence for redistributionassociated intracellular $\mathrm{pK}^{\prime}$ shifts of the $\mathrm{pH}$-sensitive fluoroprobe carboxy-SNARF-1. Pflugers Arch 427, 332-342.

Ott, M., Norberg, E., Walter, K. M., Schreiner, P., Kemper, C., Rapaport, D., Zhivotovsky, B. \& Orrenius, S. (2007). The mitochondrial TOM complex is required for tBid/Bax-induced cytochrome $c$ release. J Biol Chem 282, 27633-27639.

Pampulha, M. E. \& Loureiro-Dias, M. C. (1989). Combined effect of acetic acid, $\mathrm{pH}$ and ethanol on intracellular $\mathrm{pH}$ of fermenting yeast. Appl Microbiol Biotechnol 31, 547-550.

Pearce, L. L., Epperly, M. W., Greenberger, J. S., Pitt, B. R. \& Peterson, J. (2001). Identification of respiratory complexes I and III as mitochondrial sites of damage following exposure to ionizing radiation and nitric oxide. Nitric Oxide 5, 128-136.

Piper, P., Calderon, C. O., Hatzixanthis, K. \& Mollapour, M. (2001). Weak acid adaptation: the stress response that confers yeasts with resistance to organic acid food preservatives. Microbiology 147, 2635-2642.

Pique, M., Barragan, M., Dalmau, M., Bellosillo, B., Pons, G. \& Gil, J. (2000). Aspirin induces apoptosis through mitochondrial cytochrome c release. FEBS Lett 480, 193-196.

Power, J. J., Dennis, M. S., Redlak, M. J. \& Miller, T. A. (2004). Aspirininduced mucosal cell death in human gastric cells: evidence supporting an apoptotic mechanism. Dig Dis Sci 49, 1518-1525.

Pozniakovsky, A. I., Knorre, D. A., Markova, O. V., Hyman, A. A., Skulachev, V. P. \& Severin, F. F. (2005). Role of mitochondria in the pheromone- and amiodarone-induced programmed death of yeast. $J$ Cell Biol 168, 257-269.
Press, W. H., Teukolsky, S. A., Vetterling, W. T. \& Flannery, B. P. (1996). Numerical Recipes in $C$, 2nd edn. Cambridge: Cambridge University Press.

Priault, M., Chaudhuri, B., Clow, A., Camougrand, N. \& Manon, S. (1999). Investigation of bax-induced release of cytochrome $c$ from yeast mitochondria permeability of mitochondrial membranes, role of VDAC and ATP requirement. Eur J Biochem 260, 684-691.

Qiao, L., Hanif, R., Sphicas, E., Shiff, S. J. \& Rigas, B. (1998). Effect of aspirin on induction of apoptosis in HT-29 human colon adenocarcinoma cells. Biochem Pharmacol 55, 53-64.

Redlak, M. J., Power, J. J. \& Miller, T. A. (2005). Role of mitochondria in aspirin-induced apoptosis in human gastric epithelial cells. Am J Physiol Gastrointest Liver Physiol 289, G731-G738.

Sapienza, K. \& Balzan, R. (2005). Metabolic aspects of aspirininduced apoptosis in yeast. FEMS Yeast Res 5, 1207-1213.

Schwenger, P., Alpert, D., Skolnik, E. Y. \& Vilcek, J. (1998). Activation of p38 mitogen-activated protein kinase by sodium salicylate leads to inhibition of tumor necrosis factor-induced $\mathrm{I} \kappa \mathrm{B} \alpha$ phosphorylation and degradation. Mol Cell Biol 18, 78-84.

Severin, F. F. \& Hyman, A. A. (2002). Pheromone induces programmed cell death in S. cerevisiae. Curr Biol 12, R233-R235.

Silva, R. D., Sotoca, R., Johansson, B., Ludovico, P., Sansonetty, F., Silva, M. T., Peinado, J. M. \& Côrte-Real, M. (2005). Hyperosmotic stress induces metacaspase- and mitochondria-dependent apoptosis in Saccharomyces cerevisiae. Mol Microbiol 58, 824-834.

Somasundaram, S., Rafi, S., Hayllar, J., Sigthorsson, G., Jacob, M., Price, A. B., Macpherson, A., Mahmod, T., Scott, D. \& other authors (1997). Mitochondrial damage: a possible mechanism of the "topical" phase of NSAID induced injury to the rat intestine. Gut 41, 344-353.

Stark, L. A. \& Dunlop, M. G. (2005). Nucleolar sequestration of RelA (p65) regulates NF- $\kappa$ B-driven transcription and apoptosis. Mol Cell Biol 25, 5985-6004.

Starkov, A. A. \& Fiskum, G. (2003). Regulation of brain mitochondrial $\mathrm{H}_{2} \mathrm{O}_{2}$ production by membrane potential and NAD $(\mathrm{P}) \mathrm{H}$ redox state. J Neurochem 86, 1101-1107.

Uyemura, S. A., Santos, A. C., Mingatto, F. E., Jordani, M. C. \& Curti, C. (1997). Diclofenac sodium and mefenamic acid: potent inducers of the membrane permeability transition in renal cortex mitochondria. Arch Biochem Biophys 342, 231-235.

Votyakova, T. V. \& Reynolds, I. J. (2001). $\Delta \Psi_{\mathrm{m}}$-Dependent and independent production of reactive oxygen species by rat brain mitochondria. J Neurochem 79, 266-277.

Waterhouse, N. J., Goldstein, J. C., von Ahsen, O., Schuler, M., Newmeyer, D. D. \& Green, D. R. (2001). Cytochrome $c$ maintains mitochondrial transmembrane potential and ATP generation after outer mitochondrial membrane permeabilization during the apoptotic process. J Cell Biol 153, 319-328.

Wissing, S., Ludovico, P., Herker, E., Büttner, S., Engelhardt, S. M., Decker, T., Link, A., Proksch, A., Rodrigues, F. \& other authors (2004). An AIF orthologue regulates apoptosis in yeast. J Cell Biol 166, 969-974.

Edited by: J. G. Berman 